\title{
Research on efficient and economical treatment methods for algal pollution in landscape water
}

\author{
Liu Zehua ${ }^{1, a}$, Liu Chaolong ${ }^{1}$, Zhao Wenyu ${ }^{1,2, b, *}$ \\ ${ }^{1}$ School of Environmental Science and Engineering, Guilin University of Technology, Guangxi, Guilin, 541004, China \\ ${ }^{2}$ Collaborative Innovation Center for Water Pollution Control and Water Safety in Karst Area, Guilin University of Technology, Guilin \\ 541004, China
}

\begin{abstract}
A water body in Guilin was selected for this study. In order to find out the best dosing ratio, we conducted research experiments on combined algae removal methods and obtained a more economical and efficient mixed dosing ratio for treating water bodies. If this solution is replicated, it will contribute to the development of marine and freshwater fisheries; to the construction of a green ecosystem and human public healt.
\end{abstract}

\section{Introduction}

Algal pollution is a major problem with regard to water treatment. PAERL, H. W. et al. studies on marine algal blooms showed that enhanced foreign organic loads (DOC and POC) and enhanced foreign inorganic nutrient loads (nitrogen and/or phosphorus), etc. in the right combination can lead to the development and persistence of algal blooms [1]. To explore the source of algal blooms, HW Paerl, RS Fulton et al. determined that human activities are related to the extent and scale of cyanobacterial blooms ${ }^{[2]}$. For example, organic matter brought by human activities causes excessive algal blooms in the water bodies of tourist cities, and MA Burford, AT Revill et al. found through their study that in the presence of sewage, algal concentrations increase ${ }^{[3]}$ and can have a significant effect on the ecological balance in water bodies. L Legendre found in their study that microalgal blooms have a significant impact on benthic and pelagic food webs ${ }^{[4]}$. $\mathrm{R}$ Alonso-Rodriguez et al. pointed out that algal blooms can cause economic losses due to the death or reduced growth of fish and shrimp ${ }^{[5]}$. PR Epstein et al. isolated cholera virus from algal blooms and consumed by fish, molluscs and crustaceans and transported to several coastal communities, which can cause poisoning if inadvertently consumed by humans ${ }^{[13]}$; J Wang et al. discussed that harmful algal blooms can have multiple effects on marine ecosystems and public health, and that in areas of algal blooms. The detection of shellfish toxins in areas of algal blooms is a serious risk to human health ${ }^{[14]}$. It has been reported that red tides have occurred more frequently in China in recent years, averaging 70-80 times per year and causing direct economic losses of nearly 200 million RMB per year.Research into algae suppression is urgently needed to address the ecological and human health risks caused by algal pollution. There are many ways to remove algae, and the latest research is currently

E-mail: ${ }^{\mathrm{a}} 1004848395 @ q q . c o m$

*Corresponding author: E-mail: b zhaowenyu@glut.edu.cn directed towards HM Stoll, JR Encinar et al. proposed an equal volume of sodium hypochlorite $(2.8 \%)$ and hydrogen peroxide $(30 \%)$ in a mixture for oxidation treatment for the most complete and rapid oxidation of algal organic matter ${ }^{[6]}$. Zhiqian et al. proposed that polyaluminium chloride (PAC) is an important flocculant in drinking water and wastewater treatment ${ }^{[7]}$. However, the current method of algae removal still suffers from a lack of in-depth research on dosage and dosing methods.Therefore, exploring the effective scheme of $\mathrm{NaClO}$ combined with PAC for the treatment of algal pollution in landscape water provides new ideas for the scheme applicable to algae removal in water. To this end, a water body in Guilin was selected for this study. In order to find out the best dosing ratio, we conducted research experiments on combined algae removal methods and obtained a more economical and efficient mixed dosing ratio for treating water bodies. If this solution is replicated, it will contribute to the development of marine and freshwater fisheries; to the construction of a green ecosystem and human public health.

\section{Materials And Methods}

\subsection{Determination of raw water quality indicators}

The water sample is a landscape water in Guilin City, placed in a beaker to observe, more turbid, there is a little suspended matter, static sedimentation suspended matter can sink to the bottom, no odor and obvious color.

\section{$2.2 \mathrm{pH}$, temperature measurement method}

Take $100 \mathrm{ml}$ of water sample in a beaker and measure the $\mathrm{pH}$ value of the water sample with a $\mathrm{pH}$ meter; measure the temperature value of the water sample with a 
thermometer.

\subsection{Turbidity measurement method}

Using turbidity meter to determine turbidity, first turn on the machine to warm up, with ultrapure water to do the blank sample correction and zeroing.Each measurement first to ultrapure water to wash, and then the water sample rinse twice, wipe dry, and then measured, such as data stability, transcription.

\subsection{Algal density measurement method}

Use a microscope to count algae, wash and dry the hemocytometer plate and coverslip, cover the coverslip first, use a dropper to draw water samples from the groove next to the plate, let it cover the counting area under surface tension, adjust the microscope, find the counting area under four times to adjust the aperture and focal length to be clearly visible and then turn to 10 times to observe, adjust the clear and then turn to 40 times to observe, by constantly adjusting the focal length to count The algae in the counting area will be counted out, each sample count up and down two counting areas, and take the average value to record. Each time to count algae, the number of experiments set up in the blank sample and a group of raw water samples to exclude sampling errors. The algae count should be performed strictly according to the Analytical Methods for Water and Wastewater Monitoring (4th edition).

\subsection{PAC coagulation, sedimentation and algae removal method}

Shake the water sample well, reach into the middle of the water level of the bucket with a siphon tube, suck out the water sample into a measuring cylinder, take six groups of $200 \mathrm{ml}$ of water samples in $250 \mathrm{ml}$ beakers, individually add a certain concentration gradient of PAC (10, 20, 30, $40,50,60 \mathrm{mg} / \mathrm{L})$, the existing active ingredient of polymeric aluminum chloride is $30 \%$, set $10 \mathrm{~min}$ and 20 min under certain coagulation and stirring conditions. At the end of the time, $30 \mathrm{ml}$ of supernatant was carefully pipetted into the colorimetric tube with a $10 \mathrm{ml}$ pipette, labeled with the corresponding concentration, capped and ready to measure turbidity and algal density, and used to determine the optimal amount of PAC to be added separately.

\section{6 $\mathrm{NaClO}$ oxidation method for algae removal}

The sampling method was the same as above, and a certain concentration gradient of $\mathrm{NaClO}$ (effective concentration of $1,2,3,4,5,6 \mathrm{mg} / \mathrm{L}$ ) was added separately to the existing sodium hypochlorite solution with a mass fraction of $8 \%$ of the active ingredient, and the contact oxidation time was set to $10 \mathrm{~min}$ and $20 \mathrm{~min}$ under certain coagulation and mixing conditions. The turbidity and algal density were measured by the same method at the end of timing, and the optimal amount of $\mathrm{NaClO}$ was determined by this method.

\subsection{NaCIO-enhanced PAC coagulation, precipitation, and pre-oxidation for combined algae removal}

Based on the above optimal oxidation conditions, the addition of PAC was reduced, and the compound ratio of $\mathrm{NaClO}$ and $\mathrm{PAC}$ was set for coagulation and precipitation experiments under the same conditions. Under certain stirring conditions, the precipitation was left for $10 \mathrm{~min}$ and $20 \mathrm{~min}$, and the supernatant was taken and its turbidity and algal density were measured according to the same operation. Another group of $\mathrm{NaClO}$ optimum oxidation concentration of $50 \mathrm{mg} / \mathrm{L}$ was set as a reference for comparison.

Table1 Combined experimental dosing concentration compounding ratio

\begin{tabular}{l|l|l|l|l}
\hline $\begin{array}{c}\text { X-axis serial } \\
\text { number }\end{array}$ & $\begin{array}{c}\text { Compounding ratio1 } \\
\text { (NaClO: PAC) }\end{array}$ & $\begin{array}{c}\text { Corresponding effective } \\
\text { concentration ratio }\end{array}$ & $\begin{array}{c}\text { Compounding ratio2 } \\
(\mathrm{NaClO}: \text { PAC })\end{array}$ & $\begin{array}{c}\text { Corresponding effective } \\
\text { concentration ratio }\end{array}$ \\
\hline 1 & $4: 3$ & $40 \mathrm{mg} / \mathrm{L}: 30 \mathrm{mg} / \mathrm{L}$ & $5: 3$ & $50 \mathrm{mg} / \mathrm{L}: 30 \mathrm{mg} / \mathrm{L}$ \\
\hline 2 & $4: 3.2$ & $40 \mathrm{mg} / \mathrm{L}: 32 \mathrm{mg} / \mathrm{L}$ & $5: 3.2$ & $50 \mathrm{mg} / \mathrm{L}: 32 \mathrm{mg} / \mathrm{L}$ \\
\hline 3 & $4: 3.4$ & $40 \mathrm{mg} / \mathrm{L}: 34 \mathrm{mg} / \mathrm{L}$ & $5: 3.4$ & $50 \mathrm{mg} / \mathrm{L}: 34 \mathrm{mg} / \mathrm{L}$ \\
\hline 4 & $4: 3.6$ & $40 \mathrm{mg} / \mathrm{L}: 36 \mathrm{mg} / \mathrm{L}$ & $5: 3.6$ & $50 \mathrm{mg} / \mathrm{L}: 36 \mathrm{mg} / \mathrm{L}$ \\
\hline 5 & $4: 3.8$ & $40 \mathrm{mg} / \mathrm{L}: 38 \mathrm{mg} / \mathrm{L}$ & $5: 3.8$ & $50 \mathrm{mg} / \mathrm{L}: 38 \mathrm{mg} / \mathrm{L}$ \\
\hline 6 & $4: 4$ & $40 \mathrm{mg} / \mathrm{L}: 40 \mathrm{mg} / \mathrm{L}$ & $5: 4$ & $50 \mathrm{mg} / \mathrm{L}: 40 \mathrm{mg} / \mathrm{L}$ \\
\hline
\end{tabular}

Table2 The mixing conditions designed in the experiment

\begin{tabular}{|c|c|c|c|c|c|}
\hline Speed & PAC experiment & $\mathrm{NaClO}$ experiment & Joint Experiment & $\begin{array}{c}\text { Corresponding G-value } \\
\left(14^{\circ} \mathrm{C}\right)\end{array}$ & $\begin{array}{l}\text { Corresponding GT } \\
\text { value }\left(14^{\circ} \mathrm{C}\right)\end{array}$ \\
\hline Before start & $\begin{array}{c}100 \mathrm{r} / \mathrm{min} \text { operation } \\
\text { Dosing after } 1 \mathrm{~min}\end{array}$ & $\begin{array}{c}100 \mathrm{r} / \mathrm{min} \text { operation } \\
\text { Dosing after } 1 \mathrm{~min}\end{array}$ & $\begin{array}{l}\text { 100r/min operation } \\
\text { Dosing after } 1 \mathrm{~min}\end{array}$ & & \\
\hline Fast & $\begin{array}{c}500 \mathrm{r} / \mathrm{min} \text { operation } \\
\text { Dosing after } 2 \mathrm{~min}\end{array}$ & \multirow{2}{*}{$\begin{array}{l}80 \mathrm{r} / \mathrm{min} \text { operation } \\
\text { Dosing after } 5 \mathrm{~min}, \\
10 \mathrm{~min}, 20 \mathrm{~min}\end{array}$} & \multirow{2}{*}{$\begin{array}{l}\text { Run } \mathrm{NaClO} \text { stirring } \\
\text { first, then run PAC } \\
\text { stirring }\end{array}$} & 326.7 & 19602.0 \\
\hline $\begin{array}{l}\text { Medium } \\
\text { speed }\end{array}$ & $\begin{array}{l}150 \mathrm{r} / \mathrm{min} \text { operation } \\
\text { Dosing after } 3 \mathrm{~min}\end{array}$ & & & 64.7 & 39012.0 \\
\hline
\end{tabular}




\begin{tabular}{c|c|c|c|c|c}
\hline Slow & $\begin{array}{c}80 \mathrm{r} / \mathrm{min} \text { operation } \\
\text { Dosing after 5min }\end{array}$ & & 27.8 & 45684.0 \\
\hline
\end{tabular}

\section{Results \& Discussion}

Table3 Raw water quality index

\begin{tabular}{c|c|c|c|c}
\hline Projects & Turbidity (NTU) & $\begin{array}{c}\text { Temperature } \\
\left({ }^{\circ} \mathrm{C}\right)\end{array}$ & $\mathrm{pH}$ & Algae density (ea/L) \\
\hline Numerical value & $13.2 \sim 14.4$ & $14 \sim 18$ & $6.8 \sim 7.2$ & $1.7 \times 106 \sim 1.9 \times 106$ \\
\hline
\end{tabular}

According to the Reclaimed Water Quality Standard for Landscape Environment Water (GB/T18921-2002), the turbidity of recreational landscape environment water should be $\leqslant 5 \mathrm{NTU}$ and the $\mathrm{pH}$ is between 6.0 and 9.0. The turbidity in the raw water quality index is greater than the prescribed limit The main reason is that the water tested is introduced to the sampling site through artificial means. This means that the water has limited mobility, small capacity and limited opportunities to be purified. Furthermore, trash and other debris such as fish feed is frequently added to the sample site resulting in serious eutrophication and algae multiplication.

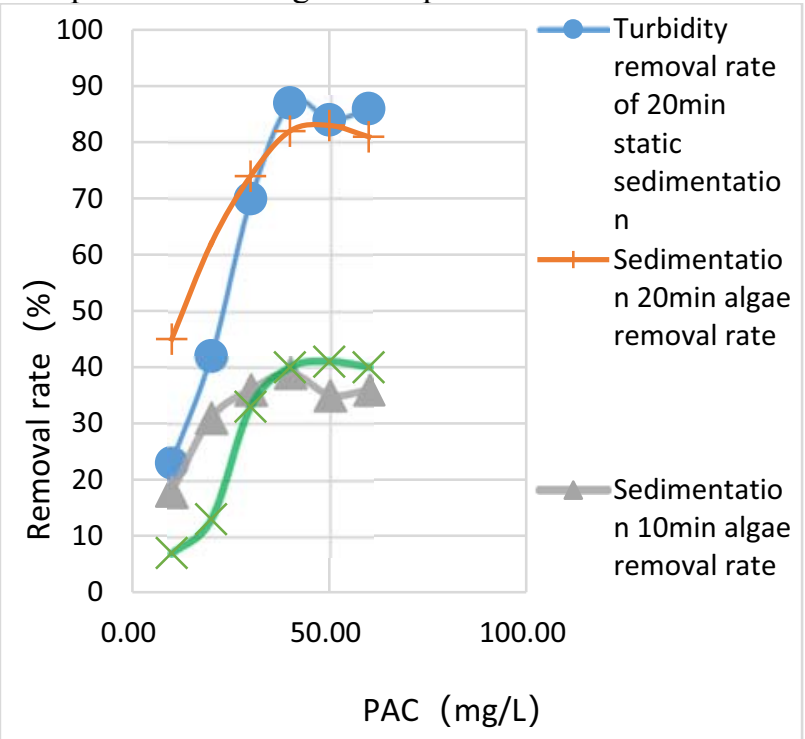

Fig1 Effectiveness of PAC coagulation and sedimentation methods for algae removal

(1) According to the removal rate of turbidity after 20 min of static sedimentation, it can be suggested that the optimal dosage is around $40 \mathrm{mg} / \mathrm{L}$.

(2) Adding PAC alone, after $20 \mathrm{~min}$ of static sedimentation, the turbidity removal rate reached $87 \%$ under the optimal dosage. Referring to the data of $10 \mathrm{~min}$ of static sedimentation, it can be concluded that the algae removal rate and turbidity removal rate showed a certain positive correlation, when the turbidity removal rate was $87 \%$, the algae removal rate was $82 \%$, and when the algae removal rate was the highest $83 \%$, the turbidity removal rate was $84 \%$.

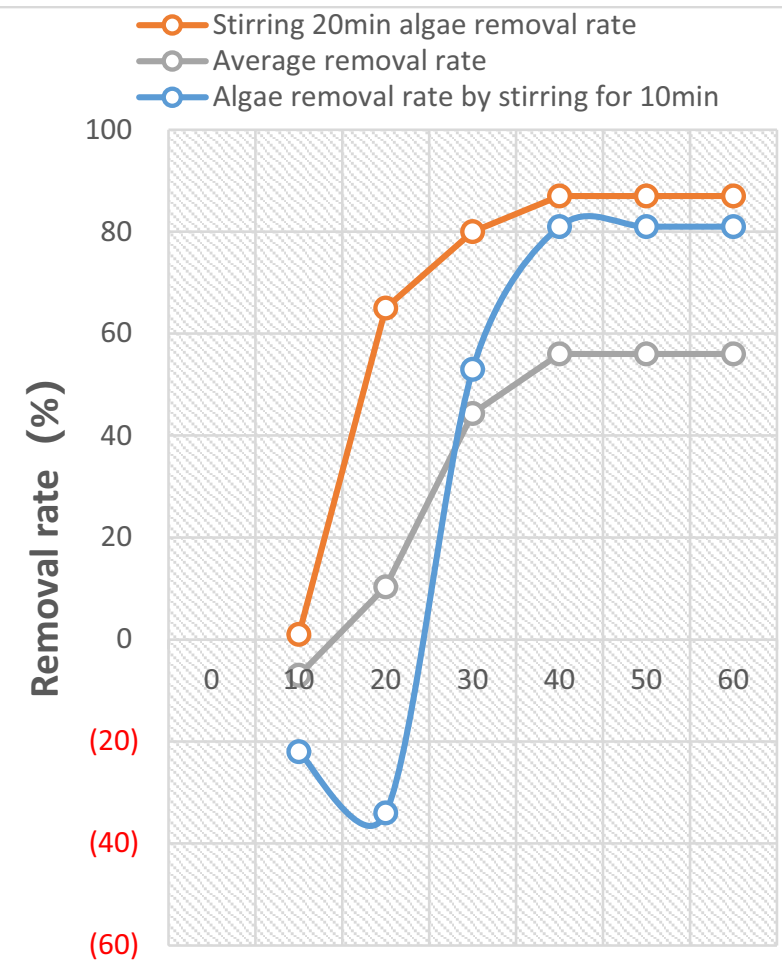

$\mathrm{NaClO}$

Fig2 Effect of sodium hypochlorite $(\mathrm{NaClO})$ oxidation on algae removal

(1) With the increase of $\mathrm{NaClO}$ concentration, the algae removal rate showed a significant increase. When the contact oxidation time was $20 \mathrm{~min}$ and the $\mathrm{NaClO}$ dosage was $40 \mathrm{mg} / \mathrm{L}$ or more, the algae removal rate did not change much, so the optimal dosage was estimated to be between $40 \mathrm{mg} / \mathrm{L}$ and $50 \mathrm{mg} / \mathrm{L}$.

(2) Under the condition of the same algae removal rate, the longer the time of contact oxidation, the less $\mathrm{NaClO}$ dosage is required. When the contact oxidation time was $10 \mathrm{~min}$ and the $\mathrm{NaClO}$ dosage was $40 \mathrm{mg} / \mathrm{L}$, the algae removal rate was $81 \%$. When the contact oxidation time was $20 \mathrm{~min}$ and the $\mathrm{NaClO}$ dosage was $30 \mathrm{mg} / \mathrm{L}$, the algae removal rate was $80 \%$. In the case of contact oxidation time of $10 \mathrm{~min}$, the algae removal rate decreased with the increase of the dosage when the dosage of sodium hypochlorite was below $20 \mathrm{mg} / \mathrm{LThe}$ algae removal rate increased with the increase of the dosage when the dosage was above $20 \mathrm{mg} / \mathrm{L}$. After the dosage reached $40 \mathrm{mg} / \mathrm{L}$, the removal rate of algae was basically unchanged. 
(3) In measuring the algal density, it was found that the species of algae that could be observed after $\mathrm{NaClO}$ injection were significantly reduced The algal cells of larger categories were not obviously green, the activity of the cells was greatly reduced, the cytoplasm of most inactivated algae leaked out, and the cells were dissolved [8].

(4) $\mathrm{NaClO}$ removes chlorophyll from microalgae, but the reduction in chlorophyll a does not characterize the reduction in the number of algal cells ${ }^{[9]}$.

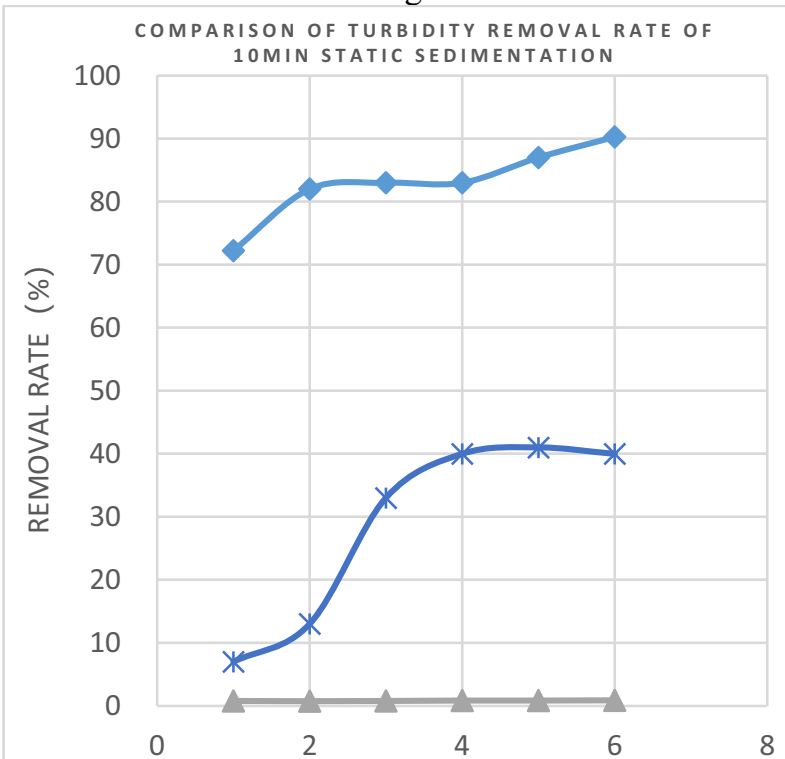

- Compound 1 turbidity removal rate of $10 \mathrm{~min}$ static sedimentation

- Compound 2 turbidity removal rate of 10 min static sedimentation

* Turbidity removal rate by adding PAC for 10 min static sedimentation

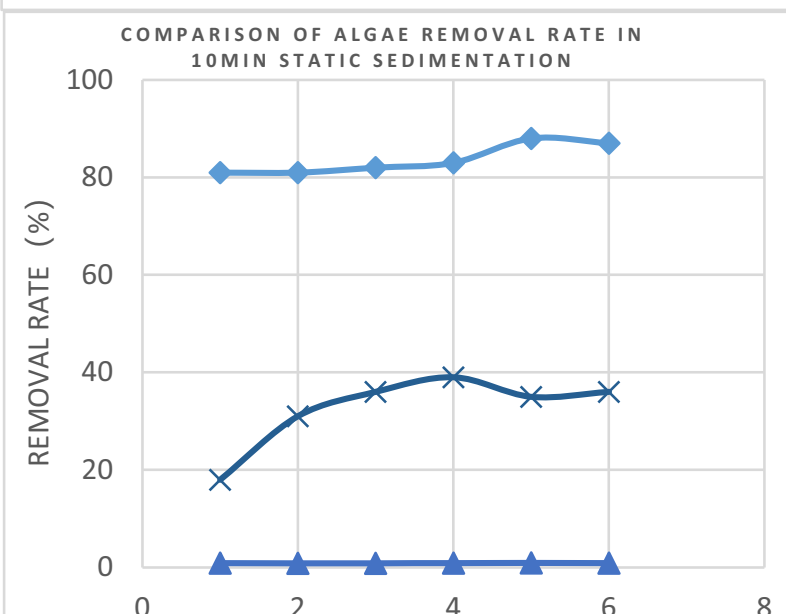

$\checkmark$ Compounding 1 static sedimentation $10 \mathrm{~min}$ algae removal rate

-Compounding 2 static sedimentation $10 \mathrm{~min}$ algae removal rate

$\rightarrow$ Algae removal rate by adding PAC for 10 min static sedimentation

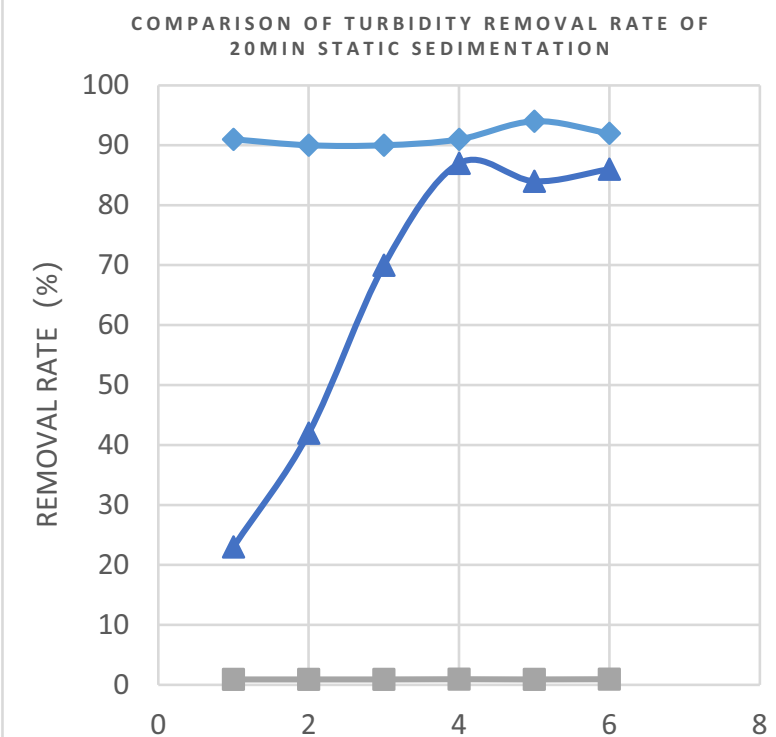

C Compound 1 turbidity removal rate of 20 min static sedimentation

- Compound 2 turbidity removal rate of $20 \mathrm{~min}$ static sedimentation

-Turbidity removal rate by adding PAC for $20 \mathrm{~min}$

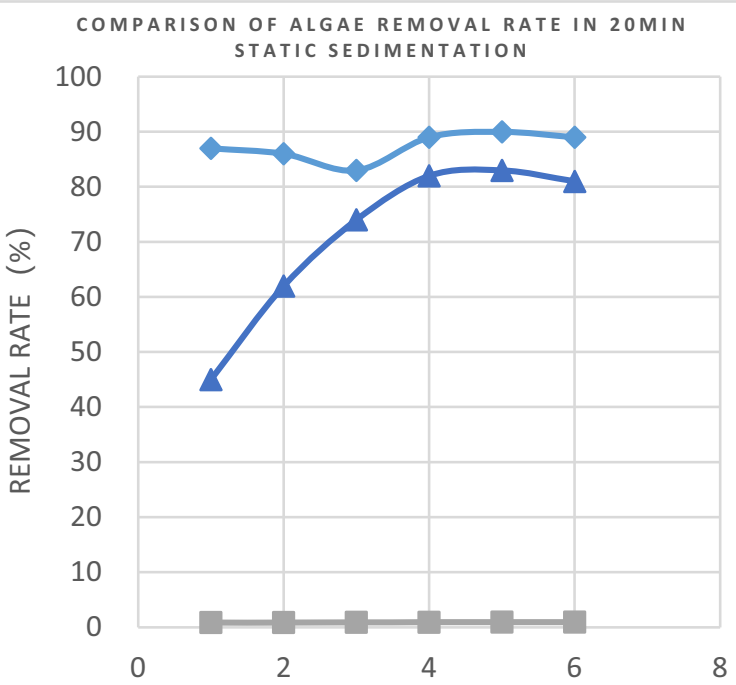

- Compounding 2 static sedimentation 20min algae removal rate

- Compounding 1 static sedimentation 20min algae removal rate

-Algae removal rate by adding PAC for 20min static sedimentation

Fig3 $\mathrm{NaClO}$ as an enhancement of the combined coagulation, precipitation and pre-oxidation of PAC for algae removal

(1) The algae removal rate was very similar after $10 \mathrm{~min}$ and $20 \mathrm{~min}$ of static sedimentation, both reaching about $80 \%-90 \%$, and with the increase of PAC concentration, the turbidity removal rate increased and the algae removal rate also increased accordingly.

(2) In the compound 1 group, the peak turbidity removal rate of $94 \%$ appeared at the PAC concentration of $38 \mathrm{mg} / \mathrm{L}$ after $20 \mathrm{~min}$ of static sedimentation, and the removal rate of turbidity in the compound ratio 2 group was $93 \%$ at this PAC concentration. 
(3) Based on the removal rate of turbidity, it can be concluded that the optimal dosing point of PAC was shifted. The PAC concentration at $40 \mathrm{mg} / \mathrm{L}$ when used alone and $94 \%$ turbidity removal rate when used in combination was $38 \mathrm{mg} / \mathrm{L}$ in the compound ratio 1 group, and the algae removal rate differed by $3 \%$ when the PAC dosage was $36 \mathrm{mg} / \mathrm{L}$ in both compound ratio 1 and 2 groups. Therefore under the condition that the treatment effect was not significantly improved when the $\mathrm{NaClO}$ concentration was increased by $10 \mathrm{mg} / \mathrm{L}$, it can be suggestedthat $30 \mathrm{mg} / \mathrm{L}$ is the best $\mathrm{NaClO}$ dosage, and the best PAC dosage is $38 \mathrm{mg} / \mathrm{L}$ under this $\mathrm{NaClO}$ dosage according to the compound ratio.

(4) Algae are colloidal substances, which are usually charged, and neutral hypochlorite molecules will adsorb on other charged colloidal particles of algae to destabilize them, so the pre-oxidation effect of $\mathrm{NaClO}$ can play a certain role in coagulation while killing algae ${ }^{[10]}$.

\section{Conclusions}

Previously, N Betzer, Y Argaman et al. proposed a method to treat algae in oxidation pond effluent using ozone-rich oxygen ${ }^{[11]}$. P Gang, C Jing, et al. proposed a new method to mitigate harmful marine algal blooms using beach sand or silica sand modified with chitosan and polyaluminium chloride (PAC) ${ }^{[12]}$. these These methods are efficient and convenient to solve the problem of large-scale algae pollution and point to a new research area for water treatment technology. This paper compares the effects of PAC coagulation, precipitation and algae removal, $\mathrm{NaClO}$ oxidation and combined algae removal (pre-oxidation and coagulation), and derives the optimal ratio of $\mathrm{NaClO}$ to PAC. In the landscape water with turbidity of 13.2 14.4 NTU and algae density of $1.7 \times 106 \sim 1.9 \times 106 \mathrm{ea} / \mathrm{L}$, the optimal dosage of PAC was $40 \mathrm{mg} / \mathrm{L}$, and the removal rate of turbidity reached $87 \%$, and the removal rate of algae reached $81 \%$ when the dosage of $\mathrm{NaClO}$ was $40 \mathrm{mg} / \mathrm{L}$ and the contact oxidation time was $10 \mathrm{~min}$, the $\mathrm{NaClO}$ :PAC was 4.3 .8 , and the sedimentation was $10 \mathrm{~min}$ : 3.8. The removal rate of turbidity reached $87 \%$ and $94 \%$ after 10 and $20 \mathrm{~min}$ of static sedimentation. Therefore, $\mathrm{NaClO}$ can greatly improve the removal rate of turbidity and algae during PAC coagulation and sedimentation, and can reduce the amount of PAC added under the premise of equivalence, but the degree of moderate oxidation of $\mathrm{NaClO}$ to water bodies with algae should also be considered. To a certain extent, this study provides a new idea for exploring the treatment of landscape water The results are of great significance in their application to water treatment in tourist areas. Water quality maintenance of water bodies in high density tourist areas promotes the tourism industry which thus has a positive impact on the social and economic circumstances in these areas. Moreover, the results of this study can inform strategies for conserving of landscape water quality since water bodies play an important role in overall ecological balance.

\section{Acknowledgments}

This study was supported by the Guangxi Scientific Experiment Center of Mining, Metallurgy and Environment (No. KH2012ZD004), by the Guangxi Talent Highland for Hazardous Waste Disposal Industrialization, and by the Collaborative Innovation Center for Water Pollution Control and Water Safety in Karst Area.

\section{Author}

First author's profile: Liu Zehua, 1999-, male, B.S., research interests: Water Treatment Theory and Technology, Water Environment Restoration and Technology, E-mail: 1004848395@qq.com, Tel.: 15765012223;

*Corresponding author: Zhao Wenyu (1973-, M, PhD, Associate Professor, Research interests: Water Treatment Theory and Technology, Water Environment Restoration and Technology, E-mail: zhaowenyu@glut.edu.cn, Tel.: 13977308172.

\section{References}

1. Anderson D M , Burkholder G J M . Harmful algal blooms and eutrophication: Nutrient sources, composition, and consequences[J]. Estuaries, 2002, 25(4):704-726.

2. Paerl H W. Nuisance phytoplankton blooms in coastal, estuarine, and inland waters[J]. Limnol Oceanogr, 1988, 33.

3. Paerl H W, Fulton R S, Moisander P H, et al. Harmful freshwater algal blooms, with an emphasis on cyanobacteria.[J]. The Scientific World JOURNAL, 2001, 1:76-113.

4. Burford M A, Revill A T, Smith J , et al. Effect of sewage nutrients on algal production, biomass and pigments in tropical tidal creeks[J]. Marine Pollution Bulletin, 2012, 64(12).

5. Legendre L. The significance of microalgal blooms for fisheries and for the export of particulate organic carbon in oceans[J]. Journal of Plankton Research(4):4.

6. Wang $\mathrm{J}, \mathrm{Wu} \mathrm{J}$. Occurrence and potential risks of harmful algal blooms in the East China Sea[J]. Science of the Total Environment, 2009, 407(13):4012-4021.

7. Alonso-Rodr??Guez R , F Páez-Osuna. Nutrients, phytoplankton and harmful algal blooms in shrimp ponds: a review with special reference to the situation in the Gulf of California[J]. Aquaculture, 2003, 219(1-4):317-336.

8. Wei H, Tang Y, Shoeib T, et al. Evaluating the effects of the preoxidation of $\mathrm{H} 2 \mathrm{O} 2, \mathrm{NaClO}$, and $\mathrm{KMnO} 4$ and reflocculation on the dewaterability of sewage sludge[J]. Chemosphere, 2019, 234:942-952.

9. $\mathrm{Hu} \mathrm{J}$, Shang $\mathrm{R}$, Deng $\mathrm{H}$, et al. Effect of $\backslash\{\mathrm{PAC} \backslash$ dosage in a pilot-scale PAC-MBR treating micro- 
polluted surface water[J]. Bioresource Technology, 2014.

10. Kamp, PC, Kruithof, et al. UF/RO treatment plant Heemskerk: from challenge to full scale application[J]. DESALINATION, 2000.

11. Betzer N, Argaman Y, Kott Y . Effluent treatment and algae recovery by ozone-induced flotation[J]. Water Research, 1980, 14(8):1003-1009.

12. Pan G, Chen J, Anderson D M . Modified local sands for the mitigation of harmful algal blooms[J]. Harmful Algae, 2011, 10(4):381-387.

13. Epstein $\mathrm{P} R$. Algal blooms in the spread and persistence of cholera.[J]. Biosystems, 1993, 31(23):209-221.

14. Wang $\mathrm{J}, \mathrm{Wu} \mathrm{J}$. Occurrence and potential risks of harmful algal blooms in the East China Sea[J]. Science of the Total Environment, 2009, 407(13):4012-4021. 